interest in neurology as well as electrophysiology. During the War of 1914-18 Keith Lucas and Adrian had discussed the new possibilities opened up by the thermionic valve, of investigating the electrical activity of the nervous system in detail. After Lucas's death, Adrian succeeded in realizing these possibilities, and in 1924 started the series of researches on the activity of single nerve fibres which in the next ten years were to yield such a rich harvest of new knowledge of the action of the sense organs and of reflex activity. As technical advances became possible these were adopted to refine the method, and his laboratory became the centre of research in electrophysiology to which research workers went from all over the world to learn these methods. The focus of work gradually moved from the investigation of the electrical activity of peripheral nerve fibres to that of nerve cells and synaptic regions of the central nervous system.

The spread of interest in brain potentials in man is largely due to Adrian's work in this field; the implications of the discoveries in this field by Hans Berger were not generally realized and the discoveries lay dormant for ten years until Adrian reinvestigated them, confirmed and extended Berger's work, and linked up his findings with general knowledge of the nervous system by animal experiments. Adrian's main interest has always been to discover the principles underlying all nervous structures as these, apply throughout the animal kingdom, and the application of these to the nervous system of man. Thus his work on the electrical activity of the nerve ganglion of the water beetle assisted him in interpreting brain potentials in man; again, experiments on single motor nerve fibres in cats led to the investigation of voluntary control of human muscles in intact man by needle electrodes, and this method has become a valuable tool to the neurologist in investigating the nature of nervous diseases. Adrian's work owes much to his manual dexterity; he carries out all details of experiments himself and constructs much of his own apparatus. $\mathrm{He}$ encourages his students to work in the same way to the surprise of some visitors who expect to find a large staff of technical assistants. The success of this policy of close contact with experimental material is attested by the large volume of research carried out by students in his laboratory, and by schools founded abroad by physiologists trained in electrophysio. logical research in Cambridge. Since Prof. Adrian's work on individual nerve cells has been complementary to the researches of the Sherrington School on reflex action and the behaviour of large numbers of neurones, it is fitting that he should join Sir Charles Sherrington in the select company of those who have received the Order of Merit.

\section{Science and Engineering in China}

IN a review of developments in China under the republican regime entitled "China To-day: The Thirtieth Anniversary of the Chinese Republic, 1911-1941" (Central Union of Chinese Students in Great Britain and Northern Ireland, Sidney Sussex College, Cambridge. Pp. 55. 1s.) there are three articles of special interest to scientific workers. The first of these, by P. M. Yap, describes the utilization of science in China, where science and statecraft are already closely linked. In peace-time, the National Economic Council is responsible for economic planning, the execution of its plans resting with the
Ministries of Economic Affairs, Agriculture and Forestry, and Communications. The former maintains three research institutes for hydraulic engineering, for mining and metallurgy, and for industrial technology. Under the Ministry of Agriculture there is the National Agricultural Research Institute, and various research bureaux are attached to the Ministry of Communications, and also directly to the National Economic Council. The National Health Administra. tion has steadily established a series of public health stations and clinies all over the country and has contributed much to the expansion and improvement of the Army Medical Service. Most of its research and development work is carried out in the National Institute of Health. Apart from the universities and private research foundations, scientific research of the long-range type is carried out by the Academia Sinica and the National Academy at Peiping, the former of which, through the National Research Council, is responsible for directing and co-ordinating scientific aetivities in China.

The difficulties which face the development of the medical profession in China are outlined in an article "Unburied Ghosts", which indicates that traditional knowledge and forms of medical practice are likely to be detrimental to the progress of medical science, particularly in view of the low proportion of medical students with a scientific outlook. A brighter picture is given by T. C. Chan in his article "Review of Chinese Engineering". Despite the persistent opposition of Japan, particularly her destruction of Chinese engineering institutes by air attack, a vigorous engineering policy has been executed. During the second stage of the War, 386 factories were transplanted into the interior, while a further 1,378 factories have been recently established in eleven industrial centres all over free China, to increase production for military and non-military needs. At the end of 1940, the number of higher educational institutions, including universities and technical colleges, was 113 , as against 108 before the War. Engineering works for communication and transport have been in full swing since 1937, and once peace is restored $\mathrm{Mr}$. Chan considers that the effective development of Chinese industries will open up a new era for the engineering world.

\section{The Royal Institution}

Tre managers of the Royal Institution have made special arrangements for carrying on the work of the Institution under the present conditions. Activities are necessarily somewhat limited by war circumstances, and many members of the staff of the Institution itself and of the Davy Faraday Research Laboratory are absent on war service. The laboratories and workshops are, however, fully employed, and a programme of lectures has been successfully carried out during the 1941-42 season. The Institution has also, with the managers' permission, been the centre for various scientific meetings and conferences in connexion with war purposes; among them, a course of special lectures, in November and December 1939, to meet the needs of students wishing to qualify for radio branches of the Defence Forces; a series of lectures on "The Nation's Larder", in April and May 1940, arranged with the approval and support of the Ministry of Food; and in September 1941, the Conference on Science and World Order, held by the Division for the Social and International Relations of Science of the British Association. It 